\title{
VALUE-ADDED TAX ON IMPORTED ELECTRONIC SERVICES: A CRITICAL EVALUATION OF THE NEWLY ENACTED SOUTH AFRICAN LEGISLATION
}

\author{
Liza Coetzee* \\ University of Pretoria \\ liza.coetzee@up.ac.za
}

Received: June 2015

\author{
Marisca Meiring\# \\ University of Pretoria \\ mameiring@deloitte.co.za
}

Accepted: November 2015

\begin{abstract}
Effective from 1 June 2014, all foreign businesses supplying digital products such as mobile applications to be used in South Africa are required to register as vendors. This amendment was made to align South Africa with an international trend of bringing cross-border supplies of electronic services into the Value-Added Tax regime. It effectively shifts the Value-Added Tax liability from the importer to the foreign supplier. The reverse-charge-mechanism resulted in an erosion of the tax base and placed local suppliers of digital services at a competitive disadvantage compared to foreign suppliers. This paper critically evaluates the amendment to the Value-Added Tax Act using a literature review. The aim is to determine to what extent the amendments address the shortcomings of the reverse-charge mechanism, are aligned with practices in the European Union and New Zealand and whether they comply with the principles of an effective tax system.
\end{abstract}

Keywords

Digital products, electronic services, electronically supplied services, imported services, reverse-charge, ValueAdded Tax, VAT

*Ms ESM Coetzee is a senior lecturer in the Department of Taxation, University of Pretoria, South Africa.

\#Ms M Meiring completed her master's degree at the Department of Taxation, University of Pretoria, South Africa. 


\section{INTRODUCTION}

The internet economy contributes approximately $2 \%$ of South Africa's gross domestic product and is growing at a rate of approximately $30 \%$ per annum. Mobile networks report that an estimated 40 million South Africans are using mobile phones, and it is expected that by 2017 more than half of those will be using smartphones (Goldstuck, 2012). South Africans are among the top downloaders of mobile applications in the world (Livdigital Independent Research Editor, 2013).

Although the expansion of internet availability in South Africa (and throughout the African continent) boosts the economy and ensures that more South Africans are globally connected, tax policies to monitor internet-related transactions have for a long time not evolved accordingly. As Value-Added Tax (VAT) is a consumption tax, it should be levied on the use of electronic services in South Africa. However, prior to the amendment of the Act, the Value-Added Tax Act, No. 89 of 1991 (the VAT Act), did not contain any place of supply rules to determine which jurisdiction had taxing rights with respect to the supply of electronic services. It was therefore not clear whether a foreign supplier had to register as a vendor in South Africa (National Treasury, 2013b). The Minister of Finance in his 2013 budget speech also singled out the collection of VAT on digital goods and services as an area in the legislation that needed to be addressed. As from 1 June 2014, place of supply rules for e-commerce transactions in line with the OECD principles, were incorporated into the VAT Act.

Previously, a reverse-charge mechanism was used to collect VAT on imported services. A South African customer who purchased digital services (such as e-books, e-music, e-movies or mobile applications) from a non-vendor foreign supplier for final consumption had to account for the VAT on the purchase. The foreign supplier was thus not compelled to register as a vendor. Apart from many practical issues surrounding the self-assessment nature of this mechanism, another major concern was that it made locally supplied goods and services less competitive. South African suppliers of electronic services had to levy VAT at 14\%, whereas foreign suppliers did not have to. Foreign suppliers were perceived to be cheaper than South African suppliers and were preferred by consumers, leading to economic inequality between the two.

A further concern was the erosion of the tax base, as VAT was not collected when South African consumers downloaded items such as applications (apps) for their cellular phones, movies, music, games and software from foreign suppliers.

The amendments effective from 1 June 2014 resulted in the tax liability being moved from the South African consumer to the foreign supplier. From this date, all foreign suppliers supplying "electronic services" to South African consumers are liable to register for VAT in South Africa and levy VAT at $14 \%$. Owing to the fact that the location of a consumer is not always known, residency in South Africa or payment from a South African bank account is deemed to be a supply to a South African consumer.

National Treasury published the Electronic Services Regulations (the Regulations) defining the term "electronic services". As from 1 June 2014 a foreign supplier of electronic services is obliged to register as a vendor as soon as the aggregate of electronic services supplied exceeds R50 000 (National Treasury, 2013b). Although originally enacted with an effective date of 1 April 2014, the implementation of the amendments was later postponed to 1 June 2014 to allow businesses to have sufficient time to get their systems ready. What complicates the situation is that electronic services excluded from the Regulations are still subject to VAT under the reverse-charge mechanism (National Treasury, 2013c). 
To date, research has been conducted on whether certain purchases made online should fall within the ambit of the provisions of the VAT Act (Johnston \& Pienaar, 2013). There has also been research in Europe regarding the kind of services that are imported electronically and where these services ought to be taxed (Parilli, n.d.), as well as the significance of the tax revenue loss if these transaction are not taxed (McLure, 2003).

The purpose of this paper is to critically evaluate the amendments to the VAT Act in order to determine the extent to which it addresses the shortcomings of the reverse-charge mechanism, the extent to which it is aligned with practices in the European Union ( $\varepsilon U$ ) and New Zealand (NZ) and whether it complies with the principles of an effective tax system. This is done by way of a literature review. After identifying the shortcomings of the reverse-charge mechanism, legislation currently in place in the EU and NZ to collect VAT and GST on imported electronic services is reviewed. Shortcomings and problems experienced in these jurisdictions are also identified. As the South African VAT Act is based on the Goods and Services Tax (GST) system of NZ, it is also critical to understand how New Zealand is treating these types of transactions. Shortcomings not addressed by the new legislation are identified and recommendations are made to address them.

\section{METHODOLOGY}

The research is conducted in the form of a literature review. The legislation applicable in South Africa before and after 1 June 2014 is reviewed. Legislation in the $E U$ and NZ is also reviewed to understand the methods used to collect VAT and GST on electronic services in those countries and what shortcomings exist. The differences in legislation are then analysed to critically evaluate the changes to the South African VAT Act.

Applicable legislation, as well as commentaries and articles accessed by way of an online search, are used for the literature review. For the purpose of the critical evaluation, commentary documents submitted to National Treasury and the South African Revenue Service on the amendments as initially proposed in the Draft Taxation Laws Amendment Bill, 2013 (National Treasury, 2013c), are used as the primary data sources. These documents were prepared by the South African Institute of Tax Professionals (SAIT) and the South African Institute of Chartered Accountants (SAICA). The submission made by SAIT incorporates the input of more than ten thousand tax practitioners and the commentary submitted by SAICA represents various large and small audit firms. These comments are then compared to the amendments as enacted in the Taxation Laws Amendment Act, No. 31 of 2013. Shortcomings not addressed by the new legislation are identified and recommendations are made to address them.

\section{LITERATURE REVIEW}

The purpose of this paper is to critically evaluate the amendments to the VAT Act to determine to what extent they address the shortcomings of the reverse-charge mechanism and to what extent they are aligned with practices in the $\varepsilon U$ and NZ. After reviewing the South African reverse-charge mechanism, legislation applicable in the $\varepsilon U$ and $N Z$ are reviewed. Lastly, the newly enacted legislation in South Africa is analysed. The outcome of these reviews is then compared and summarised in a table to indicate the differences in the methods currently applied by the different countries. 


\subsection{The South African reverse-charge mechanism}

The following hypothetical example explains the reverse-charge mechanism applicable in South Africa:

Peter, a twenty-four-year-old who lives in Pretoria (South Africa), owns an iPhone. He downloads an application for personal use on his iPhone from the iStore available on the mobile device. He has no in-depth knowledge of any taxation legislation and is not a vendor. The application being downloaded costs $\$ 30$ (R300 converted at an assumed average spot rate of $\$ 1: R 10$ ) and Peter uses his South African credit card details to make the payment.

Before 1 June 2014, iStore would have had no obligation to register as a vendor in South Africa and would therefore not have levied VAT. However, as this constitutes an "imported service" (as defined in s. 1 of the VAT Act), Peter has to pay VAT on the import. If Peter was a vendor and was to use the application in the making of taxable supplies, this would not have constituted an "imported service". To be an "imported service" the importer must be the final consumer of the service.

Peter has to submit a completed VAT2 15 form and pay R42 (being 14\% of R300) at a South African Revenue Service (SARS) branch within 30 days (s. 14 of the VAT Act). It is doubtful that the VAT of R42 will be collected due to the shortcomings of this collection method. The first shortcoming is that it relies heavily upon the honesty of the consumer. Furthermore, consumers are often unaware of the VAT liability or might think that payment is voluntary.

Secondly, the cost for SARS to enforce the legislation effectively may exceed the benefit, owing to the difficulty in identifying consumers entering into online transactions. This gives foreign suppliers a competitive advantage over local suppliers, who are required to levy VAT. This is because consumers perceive services offered by foreign suppliers to be cheaper than those offered locally, which impacts on the economic decisions of consumers. The fact that this mechanism is paper-based and that the declaration and payment cannot be made online is also identified as a shortcoming, which increases compliance time substantially.

The last shortcoming is that the current threshold of R100 per transaction (s. 14(5)(e) of the VAT Act) may lead to consumers structuring transactions in such a way that they fall below R100 in order to be exempt from VAT. For example, a consumer could do three transactions of R80 each instead of one transaction of R240, as the exemption applies to individual transactions. If a tax system is fair or equitable, the chance of tax evasion will be less.

Based on these shortcomings, the reverse-charge mechanism is inadequate in many ways and is becoming increasingly inefficient.

\subsection{The European Union}

In his 2013 budget speech, the Minister of Finance referred to the methods implemented by the $\varepsilon U$ (National Treasury, 2013a). It was confirmed in the Explanatory Memorandum that the changes aim to a lign South Africa with the principles laid down by the OECD, which are also followed by the $\varepsilon U$. Although South Africa is not a member of the $0 \varepsilon C D$, there is a working relationship and the country follows $0 E C D$ guidelines to a certain extent.

Before 2002, the place of supply of services in the $\varepsilon U$ was where the supplier had established a business, had a fixed establishment or a permanent address or usually resided (Council Directive $77 / 388 / \varepsilon \varepsilon C$ of 17 May 1997). Electronically supplied services were, therefore, taxed where the 
supplier was established, irrespective of where the services were consumed (Van der Merwe, 2004). There was no means of taxing supplies made by suppliers who did not have a fixed establishment in the $\varepsilon U$ from where the services were being supplied, leading to $\mathcal{U} U$ suppliers being less competitive than non- $\varepsilon U$ suppliers. This was seen as a problem that could potentially lead to losses for the European fiscus (Johnston, 2011).

The VAT implications of imported electronically supplied services from non- $\varepsilon U$ countries to $\varepsilon U$ established consumers were drastically reformed in 2002, driven by three elements, each of which is discussed below.

\subsubsection{Definition of electronically supplied services}

Although electronically supplied services were not defined, an indicative list was provided in Annex II of Council Directive 2006/112/عC of 28 November 2006. This list was also provided in Annex L of Council Directive 2002/38/EC of 7 May 2002, although the heading read "Illustrative List". The list includes: website supply, web-hosting, distance maintenance of programmes and equipment, supply of software and updating thereof, supply of images, text and information and making available of databases, supply of music, films and games, including games of chance and gambling games, as well as political, cultural, artistic, sporting, scientific and entertainment broadcasts and events and supply of distance teaching.

Critics point out that the list is not comprehensive (Basu, 2002) and that it does not specify how the supply should take place. Van der Merwe (2004) explained that "The EU deliberately refrained from defining imported electronically supplied services by means of a prescriptive list, because of the disadvantages of such a method: it creates problems in defining each type of service on the list, runs the risk of quickly becoming outdated, and creates a fence around which avoidance and tax planning can occur."

\subsubsection{Place of supply of imported electronically supplied services}

As from 1 July 2003, a non- $\varepsilon U$ supplier had to register for VAT in the $\varepsilon U$ if electronic services were supplied to consumers in any of the member states of the $\varepsilon U$. The place of supply is where the consumer is established, has his permanent address or usually resides (article $9(2)(f)$ to the Sixth Directive), thus where the services are consumed. These principles are supported by the OECD guidelines (Johnston \& Pienaar, 2011).

$\varepsilon U$ authorities experienced three difficulties with these rules:

- Firstly, it is difficult for the authorities of the different member states of the $\varepsilon U$ to identify non-resident suppliers (Van der Merwe, 2004).

- Secondly, it is difficult for the non-EU supplier to determine where the services will be consumed and whether the importer is indeed the final consumer of the service. The ability of the non- $\varepsilon U$ supplier to make the above determinations is inherent in the success of the system (Van der Merwe, 2004). The US Council for International Business echoed this concern, which can result in greater compliance costs for non- $\varepsilon U$ suppliers (Basu, 2002).

- The third difficulty relates to the VAT rate which the non- $\varepsilon U$ supplier should charge. VAT is levied at the rate applicable to the member state where the consumer is located, ranging between $15 \%$ and $25 \%$. As explained by Basu (2002), the non- $\varepsilon U$ supplier therefore needs to keep track of its customer's location. This problem is, however, not relevant to South Africa, 
as VAT is levied at a flat rate of $14 \%$, regardless of where in the country the service is consumed.

As from 1 January 2015, the above place of supply rules will also apply to $\varepsilon U$ suppliers of electronically supplied services (Arthur Cox, 2011).

\subsubsection{Declaration and payment of the VAT by non- $\varepsilon U$ suppliers}

The non-EU supplier has to register for VAT in every member state in which the services are consumed. As this places an administrative burden on non- $\varepsilon U$ suppliers, a special scheme (the so-called one-stop scheme) was introduced. Eligible non- $\varepsilon U$ businesses are given the option of registering electronically in a single member state of their choice. They account for VAT on their sales to all $\varepsilon U$ consumers on a single quarterly electronic VAT declaration, which provides details of VAT due in each member state (Her Majesty's Revenue \& Customs, 2003). The return must be submitted and the payment of VAT made within 20 days following the end of the reporting period to which the return refers. The return must be submitted electronically every quarter, regardless of whether electronic services were supplied in that quarter or not. The fact that all administration takes place electronically and only once a quarter eases the compliance burden.

It is clear that the success of the $\varepsilon U$ system is heavily reliant on two things: the ability to identify the consumer online and the ability of VAT authorities to trace non-compliant businesses.

\subsection{New Zealand}

Before 2001, most imported services, unlike imported goods, were not subject to GST (Olding \& Sussman, 2001). In 2001 the NZ government recognised that not taxing imported services posed a risk to the tax base and was contrary to the international framework for consumption taxes.

The subsequent changes to the Goods and Services Act, 141 of 1985 (the GST Act), provided for a reverse-charge mechanism to collect VAT on imported services. Services are treated as being supplied in NZ if these services are provided by a non-resident to a NZ resident who is the final consumer (s. 8(4B) of the GST Act). The service is deemed to be supplied by the importer-recipient in the course or furtherance of a taxable activity carried on by him (s. 5B of the GST Act). If registered for GST, the importer has to account for GST at a rate of $15 \%$. If not registered, no GST is payable.

The taxation of imported electronically supplied services is based on the following elements or principles, each of which will be briefly discussed:

\subsubsection{Definition of electronically supplied services}

"Electronically supplied services" are not specifically defined in the GST Act but are included in the definition of "services" (in s. 2(1)), being anything other than goods and money. It was, however, clarified in the tax policy discussion document (GST and imported services: A challenge in an electronic commerce environment, 2001) that digitised products are treated as services and therefore the reverse-charge will be applicable to the importation of digitised goods. Digitised goods were defined as "... goods and services that are delivered by electronic means in digital form. These products can be delivered to a computer through the internet, by way of telephone or cable network, or by satellite." 
It was also explained in the discussion document that using a generic definition as opposed to a list of services to which the reverse-charge would apply removes the need to define each type of service on the list. Furthermore, as new types of services emerge with the development of technology, a list would have to be updated, resulting in constant changes.

Therefore, although electronically supplied services are not specifically defined, the need to include digitised products in the definition of services and to clarify what they are was recognised.

\subsubsection{Place of supply of imported electronically supplied services}

In terms of s. 8(4B) of the GST Act the services are deemed to be supplied in NZ if provided by a non-resident to a resident. This is consistent with the destination principle applicable to the supply of other goods and services in NZ, taxing the services where they are consumed.

\subsubsection{Reverse-charge mechanism}

This mechanism is, in many ways, similar to that used in South Africa. It is also aimed at business to consumer (B2C) supplies, but only if the final consumer is registered for GST. In South Africa it applies regardless of whether or not the final consumer is registered as a vendor. The registration threshold for GST in NZ is taxable supplies exceeding NZ $\$ 60000$ in a 12-month period. This implies that a natural person not registered for GST in NZ would have to register and start paying GST on imported electronic services once he or she has imported services in excess of NZ $\$ 60000$ over a 12-month period (s. 51 of the GST Act).

The GST and imported services discussion document explains that the registration of foreign suppliers was also considered as an option when the GST Act was changed to tax imported services. Two difficulties with this method are, however, highlighted. Firstly, that it would be difficult to enforce since the legislation would have to be enforced offshore. Secondly, the fact that it would create compliance cost concerns for non-residents seeing that they would have to register and charge GST in NZ. It was, therefore, concluded in the discussion document that "While it is feasible for an economic bloc (like the $\varepsilon U$ ) [inserted] to implement such a system of taxation, it is questionable whether a country the size of NZ could unilaterally impose and enforce such a system."

\subsection{The newly enacted South African legislation}

As from 1 June 2014, all foreign suppliers of electronic services have to register for VAT in South Africa where their taxable supplies exceed R50 000. The tax liability therefore shifts from the importer or recipient (under the reverse-charge mechanism) to the foreign supplier (now a vendor). This was achieved by the following legislative changes:

\subsubsection{Definition of electronic services}

A new definition called "electronic services" was inserted into s. 1 of the VAT Act. Services falling under this definition are listed in the Regulations. Electronic services are grouped under the following five headings: educational services, games and games of chance, internet-based auction services, miscellaneous services and subscription services. Furthermore, the Regulations explain how the service must be supplied, namely by means of any electronic agent, electronic communication or the internet. 
The scope of the Regulations is fairly narrow so as to exclude electronic services of a business to business (B2B) nature (National Treasury, 2014). It should be noted that imported services not falling within the Regulations are still subject to the reverse-charge mechanism, but only where the importer is the final consumer. Imported services falling within the Regulations will include B2C supplies or services imported by vendors for non-taxable purposes.

\subsubsection{Definition of enterprise}

The definition of "enterprise" was amended to include the supply of electronic services by a person from a place outside South Africa to a recipient who is a resident of the Republic of South Africa (para (b) (vi) (aa) of the definition of 'enterprise' in s. 1 of the VAT Act).

This addition to the definition of enterprise establishes the place of supply of electronically supplied services and therefore deems the supply to have been made in South Africa. However, the customer's residency is often unknown to foreign suppliers. Therefore a proxy for the location is also used (National Treasury, 2013b). If payment for the electronic service originates from a South African bank account, the supply is also deemed to have been made by the foreign supplier in South Africa (para (b) (vi)(bb) of the definition of 'enterprise' in s. 1 of the VAT Act). The determination of the location of the importer was also one of the difficulties experienced by the हU. ${ }^{1}$

\subsubsection{Compulsory registration threshold}

Foreign suppliers of electronic services to South African customers become liable to register at the end of any month in which the total value of taxable supplies made by them exceeded R50 000 (s. 23(1A) of the VAT Act). Registration on the payment basis is permitted to help streamline compliance (s. 15(2) (a) (vii) of the VAT Act; National Treasury, 2013b). A lower threshold was not used to ensure that every effort is made to create equity between local and foreign suppliers of electronic services (National Treasury, 2013b). Currently, National Treasury and SARS are reviewing an increased threshold to exclude very small foreign suppliers, owing to the administrative burden (National Treasury, 2013c).

\subsubsection{Requirement to issue a tax invoice}

The foreign supplier is required to issue a tax invoice to the importer (s. 20(5B) of the VAT Act). This means that foreign suppliers will have to design specific tax invoices for supplies made to South African consumers to be able to reflect the necessary information as required by s. 20 of the VAT Act.

\subsubsection{Impact of the changes on consumers and suppliers}

Using the same hypothetical example as for the reverse-charge mechanism (Peter purchasing an application for his iPhone from iStore), the VAT treatment is now as follows:

The application will be an "electronic service" as defined (item ( $m$ ) of 'subscription services' in the Regulations). Furthermore, the application was delivered directly to Peter's smartphone using the internet. Peter is a South African resident and payment was made from a South African bank account. iStore is carrying on an enterprise in South Africa and it is assumed has already registered as a vendor in South Africa due to meeting the R50 000 threshold. iStore must issue a tax invoice to Peter for the application sold to him. The price of the application will be increased 
by $14 \%$ VAT, namely $\$ 4.20$ (or R42) and Peter now pays $\$ 34.20$ (equal to R342). iStore, acting an agent of SARS, would have to pay the VAT of R42 over to SARS.

Peter will no longer have an obligation under the reverse-charge mechanism for the payment of the VAT. It should, however, be noted that if the imported service is not listed as an electronic service in the Regulations or is not delivered in a manner set out in the Regulations, the reversecharge mechanism would still apply.

This example illustrates that the VAT liability has shifted from Peter to iStore as a result of the newly enacted place of supply rules. Furthermore, SARS is more likely to collect the VAT.

\subsection{Comparing South Africa, the European Union and New Zealand}

The following table summarises the difference between the South African reverse-charge mechanism, legislation applicable in the $\varepsilon U$ and NZ, as well as the newly enacted South African legislation to collect VAT on imported electronic services.

\section{TABLE 1: Summary of difference in legislation}

\begin{tabular}{|c|c|c|c|c|}
\hline $\begin{array}{l}\text { Element/ } \\
\text { requirement }\end{array}$ & $\begin{array}{c}\text { South African } \\
\text { reverse-charge } \\
\text { mechanism }\end{array}$ & $\begin{array}{l}\text { European } \\
\text { Union }\end{array}$ & New Zealand & $\begin{array}{c}\text { Newly enacted } \\
\text { South African } \\
\text { legislation }\end{array}$ \\
\hline $\begin{array}{l}\text { Electronically } \\
\text { supplied } \\
\text { services defined }\end{array}$ & $\begin{array}{l}\text { No - falls within } \\
\text { the scope of } \\
\text { 'imported } \\
\text { services' }\end{array}$ & $\begin{array}{l}\text { Yes, by way } \\
\text { of an } \\
\text { indicative / } \\
\text { illustrative } \\
\text { list }\end{array}$ & $\begin{array}{l}\text { No- however } \\
\text { clarified what } \\
\text { digitised products } \\
\text { are and that they } \\
\text { fall within the scope } \\
\text { of 'imported } \\
\text { services' }\end{array}$ & $\begin{array}{l}\text { Yes - as } \\
\text { described in the } \\
\text { Regulations }\end{array}$ \\
\hline $\begin{array}{l}\text { Collection } \\
\text { method }\end{array}$ & Reverse-charge & $\begin{array}{l}\text { Registration } \\
\text { of non-EU } \\
\text { suppliers by } \\
\text { utilisation of } \\
\text { place of } \\
\text { supply rules }\end{array}$ & Reverse-charge & $\begin{array}{l}\text { Registration of } \\
\text { foreign suppliers } \\
\text { of electronic } \\
\text { services by } \\
\text { introduction of a } \\
\text { place of supply } \\
\text { rule }\end{array}$ \\
\hline $\begin{array}{l}\text { Responsible for } \\
\text { declaration and } \\
\text { payment }\end{array}$ & Any recipient & $\begin{array}{l}\text { Supplier of } \\
\text { the service }\end{array}$ & $\begin{array}{l}\text { Only registered } \\
\text { recipients }\end{array}$ & $\begin{array}{l}\text { Supplier of the } \\
\text { service }\end{array}$ \\
\hline $\begin{array}{l}\text { Applicable to } \\
\text { B2C or B2B } \\
\text { supplies }\end{array}$ & Primarily $\mathrm{B} 2 \mathrm{C}$ & $\mathrm{B} 2 \mathrm{C}$ & Primarily $\mathrm{B} 2 \mathrm{C}$ & $\mathrm{B} 2 \mathrm{C}$ and $\mathrm{B} 2 \mathrm{~B}$ \\
\hline $\begin{array}{l}\text { Threshold in } \\
\text { place }\end{array}$ & $\begin{array}{l}\text { Exemption for all } \\
\text { transactions less } \\
\text { than } \mathrm{R} 100\end{array}$ & None & $\begin{array}{l}\text { Yes - registration } \\
\text { threshold of } \\
\text { NZ } \$ 60000 \text { applies }\end{array}$ & $\begin{array}{l}\text { Yes - registration } \\
\text { threshold of } \\
\text { R50 } 000\end{array}$ \\
\hline
\end{tabular}

Source: Authors' deduction 


\section{CRITIAL EVALUATION}

\subsection{Theoretical foundation}

A basic overview of the main principles (also called canons or maxims) of tax is a prerequisite for critically evaluating the newly enacted legislation. Canons or maxims of taxation are the principles laid down on which to build an effective tax system. The economist Adam Smith in his famous book, The Wealth of Nations ([1776] 2003), postulated four important canons of taxation, which he argued would ensure a fair and effective tax system.

The first canon is the Canon of Equity (also called fairness of taxes). Horizontal fairness is relevant to this paper and is based on the equal tax treatment of those in similar circumstances (Steyn, 2012), such as local and foreign suppliers of electronic services. The second is the Canon of Certainty, namely the tax payable by a taxpayer should be certain, not arbitrary. The third Canon of Convenience states that the mode and timing of tax payment should be, as far as possible, convenient to the taxpayer. Lastly, the Canon of Economy implies that the cost of tax collection should be lower than the amount of tax collected.

\subsection{Evaluating the newly enacted legislation}

The purpose of the critical evaluation is, firstly, to evaluate whether the shortcomings in the reverse-charge mechanism have been addressed; secondly, to determine to what extent the new legislation is aligned with global practices; and, lastly, whether it complies with the principles of an effective tax system. Shortcomings in the new legislation are identified below and recommendations made to address these.

\subsubsection{Definition of electronic services}

"Electronically supplied services" is a term with which international suppliers are familiar. The introduction and unfamiliarity of a new term may prevent suppliers from registering in South Africa, as it may not be clear whether or not the services supplied by them fall within this definition. This might result in making the VAT liability unclear in light of the requirements of Adam Smith's Canon of Certainty. In order to align the terminology used in the South African VAT Act with global practices, the term "electronic services" should be replaced by "electronically supplied services".

It is further recommended that a general heading be added in the Regulations, namely any service delivered via any other delivery method for which minimal human intervention is required. This additional item would ensure that delivery methods such as Bluetooth or similar means are not excluded. It is further recommended to clearly state that the Regulations are by no means intended to be an exhaustive list (similar to the EU calling it an "Indicative List"). The Regulations should be reviewed and updated annually in order to keep abreast of new technological developments (one of the reasons NZ is not using a list to define electronically supplied services).

\subsubsection{Definition of enterprise}

The first problem relates to the Canon of Certainty, as an international supplier may not be familiar with the definition of "resident" in s. 1 of VAT Act. It is, therefore, impractical and, arguably, unachievable to leave the determination of the residency of the consumer to the foreign supplier. It is recommended that the residency of the consumer be established by way of a self- 
declaration, combined with a reasonable form of identification. It is further recommended that the foreign supplier should not be held accountable if false declarations are made by a consumer. This might possibly motivate international suppliers to register in South Africa.

Secondly, the place of supply proxy requires that payment be originated from a South African bank account. If the recipient, therefore, makes payments from an offshore account, this proxy will not be applicable. It is recommended that the word "originates" be replaced with "made" or "effected" in order to diminish possible ways to avoid VAT.

Lastly, as the legislation presently stands, VAT will be levied on all supplies of electronic services, regardless of whether the importer is the final consumer. The inclusion of B2B supplies (or otherwise not excluding supplies which will be used in the making of taxable supplies) will lead to an additional compliance and administrative burden for the foreign supplier, the consumer and SARS (Terblanche, 2014). It is recommended that the supply of electronic services should be recognised as an enterprise only to the extent that it will be used by the importer or recipient for making non-taxable supplies. This will be in line with the principles applied by the $\varepsilon U$, which requires VAT to be charged only on the supply to non-registered recipients and with NZ, which charges GST only if not used for taxable supplies.

These recommendations will result in fewer foreign businesses having to register as vendors in South Africa. This in turn will ensure that they do not withdraw from the South African market. As South African suppliers will also levy VAT based on the same rules, the situation will be equitable and SARS will not have to incur high administrative costs to ensure compliance by non-resident suppliers.

\subsubsection{Registration threshold}

The fact that a R50 000 compulsory registration limit is applicable means that foreign suppliers of electronic services are not subject to similar taxation thresholds and registration requirements as South African suppliers of similar services. This places the foreign supplier at a disadvantage and seems to give rise to inequality in terms of Adam Smith's Canon of Equity. This inequality may cause foreign suppliers of electronic goods to withdraw from South Africa, to the disadvantage of South African consumers.

It is recommended that either a new registration threshold be set for both local and foreign suppliers of electronic services or that the threshold that currently applies for registration of South African suppliers in general (Rl million) should also apply to foreign suppliers.

It is further recommended that the suppliers be allowed to submit quarterly VAT returns in order to lighten the administrative burden and streamline compliance. This will be in line with the administrative requirements of the $\varepsilon U$ and Adam Smith's Canons of Convenience.

\subsubsection{Requirement to issue a tax invoice}

The requirement for a foreign supplier to issue the South African consumer with a tax invoice may discourage international suppliers from registering for VAT. This requirement could even discourage foreign suppliers from doing business in South Africa, since it places an additional administrative and compliance burden on them.

Foreign suppliers' reporting systems are not necessarily designed to include all of the information required for a tax invoice or to account for the VAT at a rate of $14 \%$. Their systems will therefore have to be re-designed in order to ensure compliance. 
It is recommended that the issue of an invoice should not be a requirement and that VAT should be payable only where the importer is the final consumer, who would not need a tax invoice to claim an input tax deduction.

\subsubsection{General comments}

In addition to the specific shortcomings discussed above, there are some general concerns with the newly enacted changes to the South African VAT Act.

Firstly, the world-wide changes designed to force suppliers of electronic services to account for the VAT or GST in the country where the service is consumed places an immense administrative and compliance burden on foreign suppliers. For example, a supplier incorporated in Australia that supplies electronic services to consumers in Switzerland, Luxemburg and South Africa will be required to register for VAT in all three countries. The Australian supplier has to account for the VAT in the appropriate manner and ensure that payments are made on time to avoid penalties and interest.

Another concern relates to the Canon of Economy. The success of the newly enacted requirements is heavily reliant on, firstly, SARS's ability to enforce compliance and, secondly, technology being available to assist SARS in doing so. The Explanatory Memorandum is silent on how compliance will be ensured and the means that will be utilised to enforce the proposals. This raises concerns that South Africa may not, owing to the size of the country and the resources available, be ready to implement changes which require significant investment in technology to enforce compliance.

The reverse-charge mechanism is still applicable where the imported services are not "electronic services" as defined. As discussed earlier, there are many shortcomings with the reverse-chargemechanism and this collection method has proved to be inadequate for the collection of VAT on electronic services.

\subsection{Summary of shortcomings and recommendations}

The possible shortcomings of the newly enacted legislation and recommendations to address these are summarised in TABLE 2.

TABLE 2: Shortcomings and recommendations

\begin{tabular}{|c|c|c|}
\hline & Shortcoming & Recommendation \\
\hline 1 & $\begin{array}{l}\text { Using terminology unfamiliar to foreign } \\
\text { suppliers. }\end{array}$ & $\begin{array}{l}\text { Change the definition of "electronic services" } \\
\text { to "electronically supplied services". }\end{array}$ \\
\hline 2 & $\begin{array}{l}\text { Definition of enterprise: the determination } \\
\text { of residency of the importer is left to the } \\
\text { foreign supplier. }\end{array}$ & $\begin{array}{l}\text { Use a self-declaration by the customer and } \\
\text { reasonable form of identification as proxy. }\end{array}$ \\
\hline 3 & $\begin{array}{l}\text { The word "originates" in the definition of } \\
\text { enterprise. }\end{array}$ & $\begin{array}{l}\text { Replace "originated" with payment "made or } \\
\text { effected" from a South African bank account. }\end{array}$ \\
\hline 4 & Both B2B and B2C supplies are included. & $\begin{array}{l}\text { VAT should be charged only to the extent that } \\
\text { the importer will use it for a purpose other } \\
\text { than the making of taxable supplies. Thus } \\
\text { include only B2C supplies. }\end{array}$ \\
\hline
\end{tabular}


Shortcoming

$5 \quad$ R50 000 registration threshold for foreign suppliers.

6 Requirement to issue a tax invoice to recipients.
Recommendation

The same threshold should apply for local and foreign suppliers of electronic services.

The issue of a tax invoice should not be a requirement, and VAT levied only on supplies to end consumers.

Source: Authors'deduction

\section{CONCLUSION}

This paper critically evaluates the amendments to the VAT Act in respect of which VAT is levied on the supply of electronic services by foreign suppliers to South African consumers. The research was carried out by way of an extensive literature review. The paper demonstrates that the new legislation does address many of the shortcomings and inadequacies of the reverse-charge mechanism. However, the reverse-charge mechanism still applies to those electronic services that fall outside of the definition of electronic services in the new Regulations.

The new legislation was also compared to legislation in the $\mathrm{EU}$ and $\mathrm{NZ}$ and the principles of an effective tax system. The paper concludes that the new legislation is, in many ways, aligned with legislation currently in place in the EU. NZ, on the other hand, uses the reverse-charge but only registered consumers are liable to pay GST on imported electronic services.

The paper identifies shortcomings not addressed by the new legislation and makes recommendations which could be used to refine the new collection method in South Africa. These recommendations are to change the definition of "electronic services" to "electronically supplied services" and using a self-declaration by the consumer, together with a reasonable form of identification to confirm the residency of a consumer. In order to limit possible ways to avoid VAT, the word "originates" in relation to payment through a bank could be replaced with "made or effected". It is also suggested that the new legislation should only apply to an importer who will be the final consumer. The issue of a tax invoice will then be unnecessary. Lastly, the same registration threshold should apply to both local and foreign suppliers of electronic services.

The paper focuses on B2C supplies. B2B supplies, as well as inter-company and inter-divisional transactions, were not addressed. It also highlights that the newly enacted method is heavily reliant on SARS's ability to enforce compliance and the availability of technology to assist SARS to achieve compliance.

${ }^{1}$ Para (b) (vi) of the definition of "enterprise" in s. 1 of the VAT Act was amended by s. 95(1)(a) of the Taxation Laws Amendment Act, No. 43 of 2014. Effective from 1 April 2015 the definition of enterprise includes the supply of electronic services by a person from a place in an export country where at least two of the following place of supply-rules are applicable:

- The recipient is a resident (para (b) (vi) (aa));

- Payment originates from a South African bank account (para (b)(vi)(bb)); and

The recipient has a business, residential or postal address in the Republic (para (b) (vi) (cc)). 
Acknowledgement

The authors acknowledge the valuable inputs of Deloitte, SAICA and SAIT by making their commentaries on the proposed legislation available to the authors.

\section{LIST OF REFERENCES}

Arthur, C. (2011). New VAT regime for 'business to consumer' suppliers of telecoms, broadcasting and electronic services. Available: http://www.techlaw.org/wp-content/uploads/2010/07/Arthur-CoxNew-VAT-Regime-for-Business-to-Consumer-Suppliers-of-Telecoms-Broadcasting-andElectronic-Services-June-2011-.pdf. (Accessed 29 July 2013).

Basu, S. (2002). European VAT on Digital Sales. The Journal of Information, Law and Technology (JILT), 2002(3). Available: http://www2.warwick.ac.uk/fac/soc/law/elj/jilt/2002_3/basu/. (Accessed 20 August 2013).

European Union. (1997). Council Directive 77/388/EعC of 17 May 1997. Available: http://eurlex.europa.eu/LexUriServ/LexUriServ.do?uri=CELEX:31977L0388:en:HTML. (Accessed 24 June 2013).

European Union. (2002). Council Directive 2002/38/EC44 of 7 May 2002. Available: http://eurlex.europa.eu/LexUriServ/LexUriServ.do?uri=0):L:2002:128:0041:0044:en:PDF. (Accessed 24 June 2013).

European Union. (2006). Council Directive 2006/112/EC of 28 November 2006. Available: http://eurlex.europa.eu/LexUriServ/LexUriServ.do? uri=0J:L:2006:347:0001: 0118:en:PDF. (Accessed 24 June 2013).

Goldstuck, A. (2012). Internet matters: The quiet engine of the South African Economy. Available: http://www.internetmatters.co.za/report/ZA_Internet_Matters.pdf. (Accessed 13 July 2013).

Her Majesty's Revenue \& Customs. (2003). VAT Info Sheet 04/03: Electronically Supplied Services: A guide to interpretation. Available: http://webarchive.nationalarchives.gov.uk/

$20110202144320 / h t t p: / / c u s t o m s . h m r c . g o v . u k /$ channels Portal WebApp/channelsPortalWebApp. portal?_nfpb=true\&_pageLabel=pageLibrary_PublicNoticesAndInfoSheets\&propertyType=document\& columns=1\&id=HMCE_CL_000907. (Accessed 20 April 2013).

Johnston, G. \& Pienaar, S. (2013). Value-Added Tax on virtual world transactions: a South African perspective. International Business \& Economics Research Journal, 12(1), pp. 71-78. Available: http://journals.cluteonline.com/index.php/IBER/article/view/7513. (Accessed 31 January 2013).

Lividigital Independent Research Editor. (2013). South Africans buying more mobile apps by the dozen. Available: http://www.livdigital.com/south-africans-buying-mobile-apps-by-the-dozen/. (Accessed 25 August 2013).

McLure, C.E., Jr. (2003). The Value Added Tax on Electronic Commerce in the European Union. International Tax and Public Finance, 10(6), pp. 753-762. Available: http://link.springer.com/article/10.1023/A\%3A1026394207651. (Accessed 31 March 2014).

New Zealand. (1985). Goods and Services Tax Act, No. 141 of 1985. Available: http://www.legislation.govt.nz/. (Accessed 12 April 2013).

New Zealand. (2001). Tax Policy discussion document. GST and imported services: A challenge in an electronic commerce environment, June 2001. Available: http://taxpolicy.ird.govt.nz/ publications/2001-dd-gst-imported-services/overview. (Accessed 12 April 2013). 
Olding, G. \& Sussman, W. (2001). Taxation. Available: http://www.bellgully.co.nz/ resources/pdfs/tax_2001_09_b.pdf. (Accessed 22 June 2013).

Parilli, D.M. (n.d.). European VAT and Imported electronically supplied services. Available: http://pubfin.nccu.edu.tw/faculty/shinemay/European_VAT_and_Electronically_ Supplied_Services_DPTI_010908\%20(1).pdf. (Accessed 12 February 2013).

Smith, A. [1776] (2003). The wealth of nations. New York, Ny: Modern Library.

South Africa. National Treasury. (2013a). Budget Review 27 February 2013. Available:

http://www.treasury.gov.za/documents/national\%20budget/2013/review/FullReview.pdf. (Accessed 1 April 2013).

South Africa. National Treasury. (2013b). Draft Explanatory Memorandum on the Taxation Laws Amendment Bill, 2013. Available: http://www.sars.gov.za/AllDocs/LegalDoclib/Drafts/LAPD-LPrepDraft-2013-29\%20-\%20Draft \%20EM\%20on\%20 the \%20 draft\%20 TLAB \% 204\% 20July\%202013.pdf. (Accessed 3 August 2013).

South Africa. National Treasury. (2013c). Draft Taxation Laws Amendment Bill, 2013. Available: http://www.sars.gov.za/AllDocs/LegalDoclib/AmendActs/LAPD-LPrim-AA-2011-02\% 20\%20Taxation\%20Laws\%20Amendment\%20Act\%202011.pdf. (Accessed 3 August 2013).

South Africa. National Treasury. (2013d). Press Release Final Electronic Services Regulation Published. Available: http://www.treasury.gov.za/comm_media/press/2014/ $2014032801 \% 20$ $\% 20$ Press\%20Release\%20-\%20Electronic\%20Services\%20Regulations.pdf. (Accessed 18 July 2014).

South Africa. National Treasury. (2014). Regulations prescribing services for the purpose of the definition of "Electronic Services". Available: http://www.treasury.gov.za/comm_ media/press/2014/2014032801\%20-\%20Government\%20Gazette\%20-\%20No\%2037489\%20on\% 2028-3\%20-\%20E-Services.pdf. (Accessed 18 July 2014).

Steyn, T.L. (2012). A conceptual framework for evaluating the tax burden of individual taxpayers in South Africa. Unpublished PhD-dissertation. University of Pretoria. Pretoria. Available: http://repository.up.ac.za/handle/2263/25182. (Accessed 18 July 2014).

Taxation Laws Amendment Act. (2013). Taxation Laws Amendment Act No 31 of 2013. Republic of South Africa.

Terblanche, V. (2014). Intragroup Transactions and E-services, Tax Talk, 46, pp. 46-49. Value-Added Tax Act. 1991. Value-Added Tax Act No. 89 of 1991. Republic of South Africa. Van der Merwe, B.A. (2004). VAT in the European Union and Imported electronically supplied services to Final Consumers. Department of Mercantile Law, 2004(16), pp. 577-588. Available: http://c.ymcdn.com/sites/www.thesait.org.za/resource/resmgr/sa_merclj(samlj)/ju samlj_v16_n4_a4.pdf. (Accessed 29 April 2013). 